\title{
The Nationality Issue on the Peripheries of Central and Eastern Europe. The Case of Polesie in the Interwar Period
}

Zarys treści: Artykuł przedstawia projekty narodowe, które zaistniały na Polesiu w okresie międzywojennym i dążyły do unarodowienia miejscowej ludności. Skrótowo zostały omówione uwarunkowania od zakończenia I wojny światowej do podpisania traktatu ryskiego w marcu 1921 r., wpływające w sposób zasadniczy na dalsze postawy Poleszuków. Województwo poleskie w granicach odrodzonej Polski było terenem współzawodnictwa ruchów narodowych: białoruskiego, polskiego, rosyjskiego i ukraińskiego. Wyraźne załamanie tej rywalizacji na Polesiu miało miejsce na przełomie 1932 i 1933 r. Od tego czasu wojewoda poleski Wacław Kostek-Biernacki zdecydowanie zwalczał wszelkie niepolskie przedsięwzięcia w regionie.

Outline of content: The article presents national projects which emerged in Polesie in the interwar period and sought to nationalise the local population. It briefly discusses the conditions from the end of World War I to the signing of the Treaty of Riga in March 1921, which significantly influenced the further attitudes of Polesians. The Polesie region within the borders of reborn Poland was the area of competition between several national movements: Belarusian, Polish, Russian and Ukrainian. The rivalry in Polesie clearly broke down at the turn of 1933. From then onwards, the Polesian voivode Wacław Kostek-Biernacki decisively combated all non-Polish undertakings in the region.

Slowa kluczowe: II Rzeczpospolita, Polesie, projekt narodowy, Białorusini, Polacy, Rosjanie, Ukraińcy

Keywords: the Second Polish Republic, Polesie, national project, Belarusians, Poles, Russians, Ukrainians

The First World War, which resulted in the breakdown of three imperial powers the Austro-Hungarian Empire, Germany and Russia, also led to a fundamental shift of nationality relations in Central and Eastern Europe. Previously existing states, such as Poland, were revived on the ruins of the empires, and completely new ones 
were emerging - Lithuania, Latvia and Estonia. Belarusians and Ukrainians also voiced their national aspirations, which, however, were not effective. It would be a great over-interpretation to claim that after the First World War the idea of the nation was eventually victorious in this part of Europe. In the case of non-historical nations, independence aspirations were often only an idea of a narrow circle of national elites, which for various reasons could have only limited leverage among its own kin. A phenomenon characteristic of the lands of the former Grand Duchy of Lithuania was the coexistence of both groups with a specific national awareness, as well as those who did not have such awareness and often identified themselves through their faith or local area. ${ }^{1}$ Even at the end of the interwar period, hermetic peasant communities may not have developed national consciousness. There is no doubt, however, that the acquisition and nationalisation of these groups became the key to effective governance in the subordinate area.

This text focuses on the problem of developing the nationality issue in the peripheral area, i.e. in the interwar Polesie. The terms "Polesie" and "Polesian voivodeship" will be used synonymously, although the first term is also a geographical notion, much broader than the administrative unit within the borders of the Second Polish Republic in 1921-1939. First, the postulates of the Belarusian, Polish, Russian and Ukrainian movements aiming to expand their influence in Polesie will be presented. The main purpose of the above claims was to nationalise the Orthodox rural population, which in number terms by far dominated the region. ${ }^{2}$ As the Jews had no national aspirations outside of their own religious community, the problem has been omitted in the present study. However, at the same time we should keep in mind that the Jewish inhabitants of Polesie accounted for about $10 \%$ of the total population of the region, and held a special place in the social structure due to their economic importance in Polesian cities and towns. ${ }^{3}$

Before World War I, the nationality issue in Polesie on the whole did not exist. In tsarist Russia, the indigenous population of Polesie was considered a Belarusian or Small Russian strain of the Russian people. The population of the region remained in a state of raw ethnographic mass, not having developed a national consciousness. National canvassing before the Great War in the area was, in fact, marginal. ${ }^{4}$ Among its few manifestations in Polesie before

1 S. Ciesielski, "Kresy Wschodnie - dynamika przemian narodowościowych", in: Kresy Wschodnie II Rzeczypospolitej. Przekształcenia struktury narodowościowej 1931-1948, ed. S. Ciesielski, Wrocław, 2006, p. 7.

2 According to the 1921 census, approximately 700,000 followers of the Orthodox Church lived in the Polesie voivodeship, which accounted for more than $79 \%$ of the total population, see Pierwszy powszechny spis Rzeczypospolitej Polskiej z dnia 30 września 1921 roku. Apartments. Population. Professional relations. Województwo Poleskie, Warszawa, 1926.

${ }^{3}$ W. Śleszyński, Województwo poleskie, Kraków, 2014, p. 89.

${ }^{4}$ L. Wasilewski, Sprawa Kresów i mniejszości narodowych w Polsce, Warszawa, 1925, p. 20. 
the First World War, the distribution of the Belarusian newspaper Nasha Niva is worth a note. ${ }^{5}$

In 1915-1920, Polesie was a military arena. Here we should only signal the changes that soon affected the attitudes of Polesians. Under German occupation, folk schools were founded in the languages of the local population, at the same time issuing a ban on using the Russian language in the area of education. Thus, Ukrainian schools created in Polesie were more an instrument of German de-Russification policy in this region than a result of the desires of the local population. According to data from August 1917, 21 Ukrainian schools functioned in Polesie, with a total of 1,250 pupils. ${ }^{6}$

Both compulsory and voluntary evacuation of the local population to the east, carried out by Russian authorities, was of great importance. Before then, the average Polesian hardly ever left their native village throughout their lifetime. In this respect, the refugee experience acquired during the civil war in Russia broadened thought horizons and brought an element of social radicalism into the life attitudes of the Polesian peasant. Repatriates coming back from Russia to their homes at the beginning of the 1920s differed fundamentally from Polesians from before the First World War. One their return home, they found a reborn Polish state, to which they were unlikely to be convinced. As a result they were quite willing to join the ranks of the communist party and legal left-wing organisations with Belarusian or Ukrainian national colouring. ${ }^{7}$ It also seems that Polonisation efforts of the authorities of the Second Polish Republic met with their resistance. According to Alfons Krysiński, by January 1923 more than 103,000 repatriates returned to Polesie. ${ }^{8}$

The conclusion of the peace treaty between the central states and the Ukrainian People's Republic, signed on 9 February 1918 in Brest, should be regarded as an important milestone. According to the agreement, Germany and its allies not only recognised the Ukrainian state, but also granted the Republic the areas of Polesie, Chełm Land and parts of Podlasie. Poland also made claims to these areas, for historical and ethnic reasons; however, the delegation from the Kingdom of Poland was not admitted to talks by any of the parties in the peace negotiations. Meanwhile, Belarusian envoys were stopped by Bolsheviks before the front line and forced to travel the long way round through Ukraine. The Bolsheviks also did not consent

5 П. Терешкович, Этническая история Беларуси XIX - начала XX в. в контексте ЦентральноВосточной Европы, Минск, 2004, р. 180.

${ }^{6}$ I. Винниченко, Українці Берестейщини, Підлящшя й Холмщини в першій половині ХХ cm. Хроніка подій, Київ, 1997, р. 37.

7 P. Cichoracki, "Działalność wywrotowa w województwach północno-wschodnich II Rzeczypospolitej Polskiej - jedno z następstw Wielkiej Wojny", in: Wojna i ludzie. Społeczne aspekty I wojny światowej w Europie Wschodniej, ed. D. Michaluk, Ciechanowiec, 2015, p. 349.

8 A. Krysiński, "Liczba i rozmieszczenie Ukraińców w Polsce”, Sprawy narodowościowe, 1928, no. 6, p. 664. 
to the participation of the Belarusian representation in the peace talks. Ultimately, Belarusians received merely the status of observers to the Ukrainian delegation. ${ }^{9}$

One effect of the Great War and the decomposition of the Russian Empire was the revival of the nationality issue in Polesie, and a shift in the existing balance of power within the region. After 1918 it became not only the setting of the rivalry between the reborn Polish state and Bolshevik Russia, but also an area of interest for Belarusian and Ukrainian national movements. The scale of their activities varied. Belarusian activists only declared their claims regarding Polesie. Following the Treaty of Brest, Ukrainians tried in vain to create local administration. The first group of Ukrainian officials set off from Kiev to Brest in April 1918. Polesie was still under the occupation power of the German military administration, which in fact did not prevent Ukrainians from pursuing cultural and educational activities. A direct participant of the events described, Vasyl Dmytriuk, recalls that it was in this period that the Ukrainian society "Prosvita" was founded in Brest. In addition, courses for teachers of Ukrainian folk schools took place three times. ${ }^{10}$

After 11 November 1918 the German occupation army, which acted as a buffer between the Polish and Bolshevik forces in this area, began to retreat at a rapid pace. A direct clash of Polish and Bolshevik troops was to resolve the political status of the territories of the former Grand Duchy of Lithuania. In February 1919, troops of the Polish Army appeared in Brest. Due to its marshy terrain, Polesie was not an area conducive to conducting warfare. In the Polesian section the Polish Army clashed with few Bolshevik troops, and on 5 March reached Pinsk.

At the same time, the internal Polish dispute over the shape of the reborn state was an extremely important factor in determining the future of the lands east of the Bug river. The Chief of State Józef Piłsudski advocated a close relationship between the lands of the former Grand Duchy of Lithuania and Poland on federal principles. For this purpose, the Civil Authority of the Eastern Territories was established, in order to create conditions for the future federation and enable the plebiscite announced in Piłsudski's appeal To the inhabitants of the former Grand Duchy of Lithuania of 22 April 1919. The period in which the Authority operated showed that convincing the population of the former Grand Duchy of Lithuania territories of the benefits of a federation with Poland would be an extraordinarily difficult task. ${ }^{11}$ On the other hand, the national camp led by Roman Dmowski propagated the direct incorporation of the eastern territories and the creation of a Polish nation-state. An intermezzo of sorts was the offensive of the Red Army and the short-term installation of Bolshevik rule in Polesie in the summer of 1920.

9 D. Michaluk, Białoruska Republika Ludowa 1918-1920. U podstaw białoruskiej państwowości, Toruń, 2010, p. 219.

10 В. Дмитріюк, Дорогами війни та миру, [n.p.] 2012, p. 59.

11 See J. Gierowska-Kałłaur, Zarząd Cywilny Ziem Wschodnich (19 lutego 1919 - 9 września 1920), Warszawa, 2003. 
Adequate Bolshevik indoctrination and an attempt to instantly change social relations strongly radicalised the local peasantry.

Disputes around the shape of Poland's eastern border lasted almost two years and ended in a defeat for the supporters of the federation concept. Signing the peace treaty of Riga on 18 March 1921 determined the annexation of the western part of Polesie to the Polish state, and in February 1921 the Polesie voivodeship was established in this area. In interwar Poland, it was an administrative unit with the smallest percentage of the Polish population. ${ }^{12}$

Further development of the nationality issue in Polesie was taking place already within the structure of the Second Polish Republic. Generally speaking, in the interwar period the region remained on the periphery of the influence of national movements. However, the greatest paradox was that the interests of many of these - Belarusian, Polish, Russian and Ukrainian - converged in Polesie. In the territorial concepts of all these movements, Polesie was an integral part to their "ideal Homeland", hence in the interwar period the region became a peculiar arena of national rivalry. It should be noted, however, that the scale of national agitation differed significantly between the individual movements. We can also observe an enormous difference in its intensity in the first and second decade of the interwar period. It would therefore be appropriate to look into the programmes of the old and new national entities in Polesie.

\section{The Polish national project}

The ethnic image of Polesie was shaped by the Orthodox peasant masses, lacking a clear national consciousness. From the point of view of Warsaw, which had a unified state apparatus, the above circumstance was not a great problem for the nationalisation of the Polesians in the Polish spirit. Without deeper reflection, it put faith in the attractiveness of Polish culture for the local population, referencing the era of the Polish-Lithuanian Commonwealth. It refused to take into account the ethnic and religious discrepancies, which in an age of increasingly growing nationalism became the foundation for constructing a modern national consciousness.

In fact, there was a conviction that the process of rebuilding post-war damages and investing in the region's economy would lead to spontaneous Polonisation of Polesians, while the passive national attitude of the local population was only supposed to speed up this process. According to the voivode Stanisław Downarowicz, "there are no efforts and sacrifices too great that Poland should not make without delay in order to carry out a broad economic programme in Polesie, which will

12 Drugi powszechny spis Rzeczypospolitej Polskiej z dn. 9 XII 1931 r. Mieszkania i gospodarstwa domowe. Ludność. Stosunki zawodowe. Województwo Poleskie, Warszawa, 1938. 
not only pay off, but which will ensure enormous national and political gains". ${ }^{13}$ His successor, Kazimierz Młodzianowski, was convinced that "one reaches the heart of this people primarily through their stomachs". ${ }^{14}$

It is worth noting that the local Polish, or potentially Polish, element played a marginal role in these plans. Poles had long inhabited Polesie, constituting in modern times the absolute majority of large landowners, although due to the anti-Polish policy of the Russian Empire authorities this percentage among them had decreased. Nevertheless, among owners of farms over 50 hectares in size, Poles accounted for $65.2 \%$. For properties of over 100 hectares, the percentage of owners of Polish nationality was even higher. ${ }^{15}$ It is symptomatic that the voivodeship administration not only failed to consider gentry as an ally in Polonising Polesie, but noted their selfish attitude and ignorance regarding the needs of the Polish cause in the region. ${ }^{16}$

The descendants of the old provincial gentry formed another, this time only potential, Polish community in Polesie. The number of nobles, who typically inhabited entire villages in tight-knit settlements, mainly in the counties of Pinsk, Stolin and Luninets of the Polesie voivodeship, was estimated at around 30,000. ${ }^{17}$ The presence of provincial gentry in the eastern voivodeships of the Second Polish Republic was particularly prominent in the second half of the 1930s. In the Polesie voivodeship, the idea of granting special protection to the gentry met with the disapproval of the local administration, which saw in it the source of additional social tensions in the countryside. It seems that in Polesie the campaign of national and religious vindication of the nobility - according to a propagator of these actions, Stanisław Dworakowski - appeared only in the sphere of propaganda. ${ }^{18}$

In the described situation of exceptional weakness of the local Polish element, some hopes were placed in the colonisation of the region. Prospects for wide-scale settlement of Polesie did not look impressive. Despite some very underpopulated

13 "Program wojewody poleskiego Stanisława Downarowicza o zadaniach i pracach państwowych na Polesiu skierowany do Wydziału Narodowościowego Ministerstwa Spraw Wewnętrznych z 28 II 1923", in: Polesie w polityce rządów II Rzeczypospolitej, ed. W. Śleszyński, BiałystokKraków, 2009, p. 36.

14 "Protokół z wystąpienia wojewody poleskiego podczas pierwszego zebrania periodycznego przedstawicieli urzędów władz II instancji w Poleskim Urzędzie Wojewódzkim z 20 VII 1925”, in: Protokoly i raporty zebrań wojewodów i starostów - województwo poleskie, ed. W. Śleszyński, Kraków, 2014, p. 30.

15 J. Tomaszewski, Z dziejów Polesie 1921-1939. Zarys stosunków społeczno-ekonomicznych, Warszawa, 1963, p. 37.

16 "Stan polskiego posiadania na Polesiu, 1939 r.", in: Polesie w polityce, p. 200.

17 O. Grott, Instytut Badań Spraw Narodowościowych i Komisja Naukowych Badań Ziem Wschodnich w planowaniu polityki II Rzeczypospolitej Polskiej na Kresach Wschodnich, Kraków, 2013, p. 201.

18 An example of such propaganda were the unjustified estimates of the number of provincial gentry in Volhynia and Polesie, which according to Dworakowski reached over 300,000, see S. Dworakowski, Szlachta zagrodowa we wschodnich powiatach Wolynia i Polesie. Relacje z terenu, Warszawa, 1939. 
areas, it lacked farmlands. The sparsely inhabited terrains were largely covered with marshes and wetlands. This factor, along with the effective failure of the drainage project and the extremely high natural increase of the local population, left no illusions regarding the plans for colonisation. In addition, settling was prevented by the complete social and economic unattractiveness of Polesie, often associated "with the worst corner, far from the world and people". ${ }^{19}$ The message in relation to Polesie - as a region completely isolated from civilisation - repeatedly appeared in Polish journalism and popular literature. ${ }^{20}$

In this situation, the extent of the impact Polishness had on the average Polesian almost completely coincided with the scope of the activities of Polish administration. It tried to engage the state apparatus, schools and the army to carry out social work. The Catholic Church, unambiguously associated in the eastern territories with Polishness, could not have had a large foothold in Polesie due to the dominance of the Orthodox Church in the area.

Undoubtedly, it was mainly the immigrant population that propagated Polishness in the region, however they were poorly acquainted with local reality. For many newcomers from other parts of Poland, a move to Polesie was tantamount to a kind of exile. Very often, they were individuals who had been discredited in their previous positions. Some officials had even been charged with criminal offences. ${ }^{21}$

The situation likely remained essentially unchanged in the second decade of the interwar period. The decision to transfer even a high-ranking official of the Ministry of Education from the Dąbrowa Basin to Polesie in 1935 met with real resentment, which can be expressed in just one sentence: "I travelled to Brest with a heavy heart, reluctantly and out of necessity". ${ }^{22}$

It seems that the most effective - although temporary - means of promoting the values of Polishness was military service. The conscripts from Polesie were usually assigned to units stationed in a more developed western and central parts of the country. For less aware Polesians, it was often a two-year trip to another world. No doubt some of the reservists, on return to their homeland, gave in to Polish influences, which for a conservative Polesian society were associated with lordliness. Military reports suggested that "in the army, Belarusians are Polonised fairly quickly, although vacations counteract this as their friends mock them for

19 The National Ossoliński Institute, Manuscript Department (hereafter: ZNiO DR), no. 16731/II, mf 35885, Stanisława Cybulska-Białowieska, “Moje wspomnienia (lata 1922-1945)”, p. 2.

20 See П. Ціхарацкі, “"Паляшук” - аб’ект цывілізацыйнай місіі і пакрыўджаны суайчыннік. Праваслаўныя вясковыя жыхары Палескага ваяводства ў польскай папулярнай літаратуры міжваеннага перыяду, Arche, 2014, no. 7-8.

${ }^{21}$ L. Wasilewski, Wspomnienia 1870-1904 (1914). Fragmenty dziennika 1916-1926, diariusz podróży po kresach 1927, eds. J. Dufrat, P. Cichoracki, Łomianki, 2014, p. 331.

22 ZNiO DR, no. 15641/II/t.1, mf 10159, Antoni Zięba, "Pamiętnik pedagogiczny. Wspomnienia i refleksje", vol. 1 [years 1900-1939], p. 285. 
their lordly whims, in which their surroundings include manners and caring for one's appearance". ${ }^{23}$

The Polish sociologist Józef Obrębski was quite sceptical in his evaluation of the prospects for rapid assimilation of Polesians, noting the huge social distance between a native Polesian and a Pole. For most Polish newcomers the local folk culture was unambivalently associated with backwardness and savagery. For the average Polesian, adopting Polish culture meant not only rejecting the existing cultural patterns, but also detachment from the rural environment. ${ }^{24}$ However, the possibility of social mobility in Polesie was minimal.

A fundamental alternative to the activities of the Polish administration in Polesie in the 1920s was proposed by Polish left-wing groups - the Polish Socialist Party (PPS) and the Polish People's Party (PSL) "Wyzwolenie". The activity of the Polish left in Polesie in the first decade of the interwar period was, in any case, a perfect example of rapid domination of an area with no previous political traditions. ${ }^{25}$ Inflowing emissaries set up structures of the PPS and PSL "Wyzwolenie" in the Polesian countryside, exerting a strong influence on the local peasants. In their canvassing they called for wide-ranging social reforms in the Borderlands, using slogans which were almost Bolshevik in nature. ${ }^{26}$

In terms of the nationality issue, they declared equality of all citizens of the Polish state regardless of their nationality and religion. At the same time, the approach of the PPS on national and linguistic issues was somewhat ambivalent. At one of the party rallies in the Pinsk county, Józef Dzięgielewski, a PPS deputy, said that "the Belarusian land should belong to Belarusians", but simultaneously called the assembled audience to study "no matter in what language, because knowledge is always the same". ${ }^{27}$

Polish leftist groups were strong opponents of both Polish nationalism, and too much exposure of national minority particularisms. As a result, they disapproved of national minorities forming their own left-wing factions. The Polish left in Polesie used Russian during agitation, mainly for tactical reasons, and released the party's publications in Russian. The Polishness of left-wing groups did not prevent gaining political influence in Polesie, while the activity of these parties, primarily due to social radicalism, was unacceptable to the state administration. The activity of these political entities had likely a minimal impact on the process of raising the national awareness among Polesian peasants. One may therefore

${ }^{23}$ K. Gomółka, Białorusini w II Rzeczypospolitej, Gdańsk, 1992, p. 142.

24 J. Obrębski, Polesie, ed. A. Engelking, Warszawa, 2007, p. 536.

25 P. Cichoracki, Województwo poleskie 1921-1939. Z dziejów politycznych, Łomianki, 2014, p. 130.

26 E. Massis, "Próby wykształcenia tożsamości narodowej u ludności słowiańskiej na Polesiu w pierwszych latach II Rzeczypospolitej Polskiej (1920-1928)”, Adeptus, 2015, no. 5, p. 5.

27 Państwowe Archiwum Obwodu Brzeskiego (hereafter: PAOB), no. f. 2001, op. 4, d. 1998, "Meldunek sytuacyjny nr 18 z dnia 25.01.1925 z Poleskiego Urzędu Wojewódzkiego do Ministerstwa Spraw Wewnętrznych", f. 57. 
presume that the politicisation of Polesie had an ultimately negative impact on the prospects of its Polonisation, as in this way it attacked the state structures which in a way promoted Polishness in these areas.

The factor of civilisational backwardness played a key role in the failure of the polonisation campaign in Polesie. The wave of civilisational changes implemented by the Polish state in this region in the interwar period could not provide the local population with wide opportunities for social advancement. In individual cases, the promised rapid Polonisation of Polesians took on the character of acculturation. Warsaw was somewhat rashly convinced of the progress of Polonisation after hearing the optimistic reports from Brest in the second decade of the interwar period. Despite the wide-scale Polonisation effort, the emotional relationship of the Polesian peasant with the Polish state at the end of the 1930s was still faint.

\section{The Russian national project}

In the political thought of the Russian Empire, Polish Eastern Borderlands were considered the western periphery of the Empire, and in the period of the partitions of Poland - an area of Polish-Russian rivalry. After the Treaty of Riga, many supporters of the imperial Russian ideology found themselves within the borders of reborn Poland against their will. Being a follower of the idea of the "one and indivisible Russia" and propagating Russianness was perceived as an attack on the territorial integrity of the Second Polish Republic.

As a result of Russification activities in the Russian Empire, some of the indigenous population of Polesie considered themselves Russian. Influences of the strongly Russified Polish petite bourgeoisie were particularly evident in DavydHaradok and its surroundings, where the local Russians constituted the majority in the city council. ${ }^{28}$ At this point, it is worth mentioning a brief but clear description of the community with Russian attitudes in Pinsk. "The Pinsk townspeople despise peasant clothes, peasant customs and language. They like to sing vulgar Russian songs, and consider themselves Russian. Their mentality, of course, has nothing to do with Russianness, and their affinity with Russians plays an essential role here". ${ }^{29}$

The idea of the "great Russian nation" was not yet an anachronism in Polesie of the interwar period. The Russian-language newspaper Under the Polesie Sky, published in Pinsk, in the run-up to the 1931 census called "every Polish citizen of Russian nationality (Great Russian, Belarusian, Small Russian) to state that their mother tongue is Russian". ${ }^{30}$ Polesian activists of the Russian National Union treated the Russian nation even more broadly, including Ukrainians, Belarusians,

28 А. Ильин, “Всплеск русского движения в Давид-Городке в 1928-1931 годах”, in: Берасиейскі хранограф: зб. навук. праи., еd. М. Часноўскі, по. 4, Брэст, 2004, р. 142.

29 Ф. Одрач, "Наше Полісся”, Пам'ятки України, 2002, по. 3-4, р. 15.

30 Под небом Полесья, 6 November 1931, no. 6, p. 1. 
Russians, Ruthenians and Polesians. ${ }^{31}$ Activists of the Union of Russian Minority Organisations in Poland, at the same time advocates of a more modern definition of Russianness (a Russian was one who consciously considered himself or herself to belong to the Russian nation) did not have large influence in Polesie. ${ }^{32}$

Nevertheless, many Russians in Polesie could find themselves in the new reality. It is symptomatic that Russians were often over-represented in the state apparatus, especially on its lower levels. In 1932, out of the twelve officials in the Luninets starosta office, eight still declared Russian nationality. ${ }^{33}$ In conversations with members of public, such officials used the Russian language, which in the opinion of Polish authorities favoured the Russification of Polesians.

In addition, a dozen prominent Russian activists lived in Polesie. The most vital political achievement of the Russians was Pavel Korol winning the deputy seat in the Pinsk constituency in 1928. The success of the Russian list proved to be unpredictable for the authorities. ${ }^{34}$ At the same time, Russian circles received an argument for the demagogic claims that Polesie was the most vibrant centre of Russian life in Poland. There were also unjustified hypotheses about a million-strong Russian community in Poland and a close-knit mass of Russians living in Polesie. ${ }^{35}$

The popularity of the "one and indivisible Russia" idea was strongly fostered by the universality of the Russian language in the public sphere. Russian, despite losing its official language status, still held a high social position. The average Polesian was convinced that a command of the Russian language was a sign of education. They could communicate in Russian with local Jews, as even at the end of the interwar period Polesian Jews were likely to use this language. ${ }^{36}$ Finally, rather scathing comments were published in the Warsaw daily Za Svobodu! on the distribution of Russian-language Polish press in Polesie. According to the Polesian landowner Aleksander Kisłowski, this fact was tantamount to acknowledging the presence of Russians in Poland and their growing influence. ${ }^{37}$

The Orthodox Church in Polesie used almost exclusively the Russian language. Of particular interest is the fact that the Russian language was also used by "sectarians" in their liturgical practice - representatives of new Protestant movements who broke away from the Orthodox Church. This state of affairs began to gradually change in the 1930s, when the voivode of Polesie Wacław Kostek-Biernacki

31 В. Мисиюк, “Исследование национальных процессов в Восточной Европе на примере Полесского воеводства (1921-1939 гг.)”, Перекрёстки, 2007, no. 3-4, p. 236.

32 В. Швайко, “Русская диаспора в Польше в 20-30 гг. XX в.”, Диаспоры, 2004, no. 2, p. 198.

33 "Article 'Akcja nacjonalistów rosyjskich na Polesiu' from the newspaper Jutro Pracy, Biuletyn Polsko-Ukraiński, 2 October 1938, no. 37, p. 412.

${ }^{34}$ Cichoracki, Województwo poleskie, p. 264.

35 "Referat sporządzony przez Wydział Bezpieczeństwa Urzędu Wojewódzkiego Poleskiego o ruchu i wpływach rosyjskich na Polesiu z 27 VI 1933”, in: Polesie w polityce, p. 80.

${ }^{36}$ L. Sobociński, “Zdobywamy zjudaizowany Wschód”, Tęcza, November 1938, no. 11, p. 33.

37 “Польские газеты на русском языке”, За Свободу!, 15 February 1928, no. 37, p. 3. 
took steps towards Polonising the Orthodox Church. A natural barrier in these plans was the lower clergy, who had been brought up in the traditions of tsarist Russia and hardly knew the Polish language. Among Orthodox priests in Polesie there were also individuals with strongly pro-Russian attitudes. In 1928, during the election campaign, this group acted against the wishes of the Pinsk Archbishop Alexander, who recommended support for the Non-Partisan Bloc for Cooperation with the Government (BBWR). Some Orthodox priests during religious services explicitly called to vote for Russian National Union candidates, and distributed the Union's pre-election appeals. ${ }^{38}$ Moreover, a phenomenon characteristic of this group of Orthodox clergy was the deeply rooted nostalgia for the Russian Empire and the cult of the tsar. In November 1932, the starosta of Drahichyn reported that on the initiative of the parish priest Rusiecki, and with the participation of local people in the village of Lyakhavichy, a mourning service for Tsar Nicholas and the House of Romanov was celebrated. ${ }^{39}$

In the conditions of almost completely Polonised educational system in Polesie, the Russians tried to open private educational establishments. Private Russian middle schools existed in Brest, Luninets and Pinsk. The last two establishments did not survive long, and in the years 1921-1939 a private Russian primary and secondary school operated in Brest. The teaching process in these institutions directly referred to the principles prevailing in the Russian Empire. It should therefore be assumed that the middle school was a form of refuge for the ancien régime, a place for maintaining and propagating Russianness. In the 1930s in particular, this school was probably the most important Russian centre in Polesie. ${ }^{40}$

In 1923, the Ukrainian community of Brest tried to transform these establishments in line with its own plans. Their intention was to introduce the Ukrainian language into the system of education on a par with Russian. Ultimately, this idea met with great resistance from the Russians and no changes were made ${ }^{41}$ From 1924 the care over Russian schools was taken over by the Russian Charity Society, whose aim was to support the cultural and educational activities of the Russian minority in Poland. Centres and libraries of the Society worked almost exclusively in urban areas, hence bringing the Polesian peasant round to the Russian cause seemed unlikely.

The ideological cement for the supporters of the Russian national project in Polesie was the nostalgia for the Russian Empire and the belief in the rapid return of the Russian rule in the "lost territories", into which Polesie was undoubtedly included. We could therefore risk a hypothesis that the stabilisation of the Bolshevik

38 PAOB, no. f. 1, op. 9, d. 503, "Duchowni prawosławni - agitacja przedwyborcza”, f. 7.

39 PAOB, no. f. 1, op. 9, d. 2202, "Nabożeństwa żałobne za cara Mikołaja”, f. 7.

40 The Central Archives of Modern Records in Warsaw (hereafter: AAN), Voivode Office in Breston-the-Bug, no. 19, "Sprawozdanie sytuacyjne nr 4 za kwiecień 1934 r.”, f. 29.

${ }^{41}$ М. Монтвилов, Русская гимназия в Бресте на Буге 1919-1939 г2., Ним-Брест-Минск, 1996, p. 40 . 
power in the Kremlin caused growing frustration and decline of Russian activity in Poland from year to year. A local factor was the change in the post of the Polesian voivode in 1932. It is a known fact that the voivode Kostek-Biernacki did not have even the slightest sympathy with Russians. ${ }^{42}$ As early as in 1934 a report from Luninets was published on the pages of the newspaper Nashe Vremya about the deplorable state of the Russian cause in the Polesian province. ${ }^{43}$ The views of the radicals among Russian activists in Polesie probably evolved in the direction of the so-called smena vekh ("a change of milestones"). The fate of the participants of the informal Russian youth circle in Pinsk seem to confirm this observation. Its unofficial leader Mikhail Kluchenovich, before he was expelled from Poland in 1933 as a "troublesome foreigner", applied for the possibility of a legal leave to the Soviet Union. In turn, after September 1939 the monarchist Basil Korotishevskiy quickly found work within the propaganda system of the new power. ${ }^{44}$

\section{The National Belarusian and Ukrainian projects}

In the interwar period, Polesie became the target of national claims of Belarusians and Ukrainians. They were stateless communities with remarkably peasant social structure, and so it seems reasonable to compare the Belarusian and Ukrainian influences in Polesie. We should start by stating that in the interwar period Polesie was not a setting of fierce competition between Belarusians and Ukrainians. In potential situations of conflict, a compromise was usually reached. An example of such agreement was the division of constituencies between Belarusians and Ukrainians during the parliamentary campaign of 1922. As a result, the first places on the lists of the Bloc of National Minorities in the Brest constituency was given to Ukrainians, and in Pinsk - to Belarusians. At the same time, it should be noted that this agreement did not, from the point of view of both sides, determine the nationality of the inhabitants of the contested territory. ${ }^{45}$

Nevertheless, the interests of the Belarusian and Ukrainian movements in Polesie did not intersect very often. This was mainly due to the differences of the potential impact of the Belarusian and Ukrainian national idea on the Polesian peasant. To Ukrainians, Polesie was an area which was difficult to access not only due to the features of its terrain, but above all its peripheral location in relation to Eastern Galicia. The young and structurally undeveloped Belarusian movement did not, on the other hand, have great resources at its disposal, with very

42 P. Cichoracki, Droga ku anatemie. Wacław Kostek-Biernacki (1884-1957), Warszawa, 2009, p. 288.

43 “Вызываем Лунинец!", Наше время, 24 October 1934, no. 249, p. 4.

44 Seе A. Ильин, “Шалаш поэтов”, Гістарычная брама: гісторыя і культура Палесся, 2004, no. 1, http://brama.brestregion.com/nomer22/artic21.shtml (access: 29 May 2017).

45 А. Пашкевіч, “Нацыянальныя працэсы ў Палескім ваяводстве ў 1920-я гг. праз прызму вынікаў выбарчых кампаній у польскі парламент”, Arche, 2013, no. 4, p. 114. 
limited possibilities for action in Polesie in both geographical and organisational terms. In 1922 Belarusians spent a meagre amount on pre-election canvassing in the Polesie voivodeship in comparison with the Nowogródek voivodeship. ${ }^{46}$ This suggests that not only did they have no money, but also no active members in Polesie. The Belarusians' shortcomings were skilfully used by the PPS, winning three deputy seats in the Pinsk region. However, in the Brest region the Bloc list won with two candidates of Ukrainian nationality. ${ }^{47}$

Another test of the vitality of the Belarusian and Ukrainian movements in Polesie was the campaign collecting signatures in order to open state schools with Belarusian or Ukrainian as the language of instruction. It became particularly intensive in the school year 1925/1926, after the so-called Lex Grabski law entered into force. ${ }^{48}$ During that period, Ukrainians managed to collect 6,239 signatures, while Belarusians - only 1,343. Most Ukrainian declarations came from three counties: Brest, Kobryn and Drahichyn. In addition, in the Kosava county, ethnically more Belarusian, Ukrainians managed to convince 116 people. The Belarusian school campaign was limited to the Pruzhany county. ${ }^{49}$

Finally, let us quote the opinion of voivode Jan Krahelski from August 1932 on the development of ethnic relations in Polesie, although it is worth remembering that the Belarusian movement at that time functioned in essentially different political reality. At the same time the voivode described the results of the 1931 census as almost hilarious, since they showed a huge reduction in the level of national awareness. According to Krahelski, the number of Ukrainians in Polesie was heavily underestimated. The voivode pointed out the serious progress of Ukrainian propaganda among the people of the southern part of Polesie, which had already felt a sense of national belonging. He also expressed a rather negative view about Belarusians, anticipating the disappearance of the Belarusian movement in Polesie. He believed that:

The Belarusian movement, territorially large-scale, with its very low, throughout the whole territory, development of national awareness, with absence of its own intelligentsia and own cultural achievements, may not meet the challenges it sets itself, and left to its own devices - if Polish state labour will develop at a rapid pace - will either die completely, or will be forced to significantly reduce its territorial aspirations... ${ }^{50}$

${ }^{46}$ Ibid., p. 116.

47 The results of the 1922 election campaign in Polesie have been discussed in detail by Cichoracki, Województwo poleskie, pp. 127-133.

48 Law of 31 July 1924 containing some provisions on the organisation of education (colloquially referred to as Lex Grabski) - a law regulating the issue of education for national minorities, introduced in 1924. It introduced bilingual (Utraquist) schools as a basic school model. In the opinion of national minorities, the purpose of the law was to denationalise pupils of non-Polish origin.

49 Cichoracki, Województwo poleskie, p. 48.

50 PAOB, no. f. 1, op. 9, d. 2253, "Memoriał Pana wojewody Jana Krahelskiego do Pana Ministra spraw wewnętrznych o stosunkach narodowościowych na Polesiu”, August 1932, f. 3-7. 
On the other hand, the nationally aware Belarusians and Ukrainians had no doubt that Polesie belonged to the Belarusian or Ukrainian national territory. Among such activists the Polesian was treated as a Belarusian or a Ukrainian primarily for linguistic reasons. Using a dialect similar to the Belarusian or Ukrainian language was considered an objective characteristic, which in a way determines the national belonging of an individual. The question of the undeveloped national awareness of Polesians did not play any role in this case. Even in its dialect variety, language was, according to those raising national awareness, a value that had to be nurtured. The Belarusian activist and Uniate priest Vaclav Onoshko in his parish in the Stolin county told off unruly youths for using Polish instead of the "native Belarusian language". ${ }^{51}$ The Ukrainian activist Olena Kysilevska, who travelled to Polesie several times in the 1930s, ended her report from the area with a rather poignant epilogue: "I am convinced that this part of our nation, although distant, but related to us through blood, language and history, will sooner or later join us spiritually - this is how it has to be! - in one, Ukrainian sea". 52

In the reality of the Polesie voivodeship, the national campaign could reach its audience only in conjunction with slogans of radical social change. In the impoverished Polesian countryside this type of rhetoric found fertile ground and could mobilise a large group of followers in a short space of time. Most Belarusian and Ukrainian activists in Polesie sympathised with, or belonged to radical left-wing groups. Representative of the Belarusian movement was the Belarusian Peasants' and Workers' Union (the Hramada), which for obvious reasons did not survive there for too long. Its equivalent on the Ukrainian side was the Sel-Rob. In the opinion of Polish authorities, both organisations were nothing more than legal annexes of the Communist Party. The Communist Party of Western Belarus (CPWB) was the main one to operate in Polesie, although in the second decade of the interwar period the southern peripheries of the Polesie voivodeship were dominated by centres of the Communist Party of Western Ukraine (CPWU). ${ }^{53}$

In political terms, however, the Ukrainian movement in Polesie was more diverse. Its moderate activists focused primarily around the "Prosvita" centres in Brest and Kobryn. It was a group of supporters of the Ukrainian National Democratic Alliance (UNDO) and the so-called Petliurovets - members of Ukrainian military formations under the command of Ataman Petliura. Ideological friction in the Ukrainian circles often adversely affected the activities of "Prosvita"; for instance, in the Kobryn centre there was a conflict regarding subscription of Ukrainian press. The Sel-Rob minority wanted to subscribe to left-wing newspapers

51 PAOB, no. f. 1, op. 10, d. 2229, “Akcja unijna - informacje”, December 1934, f. 11.

52 О. Кисілевська, По рідному краю, Коломия, 1935, p. 128.

53 P. Cichoracki, Komuniści na Polesiu w latach 1921-1939, Łomianki, 2016, p. 29. 
Svitlo and Nashi Zhyttya, while most others preferred to read Dilo - the official press organ of the UNDO. ${ }^{54}$

The Belarusian national-democratic parties had only individual supporters in Polesie. Belarusian Christian Democracy tried to set up its facilities in the Pruzhany county; these activities remained ineffective. ${ }^{55}$

The Belarusian and Ukrainian cultural and educational activities in Polesie were carried out within the framework of the Belarusian School Society and "Prosvita". The two organisations in principle tried to suggest an alternative to the Polonisation of the educational system and public life in Polesie. In 1928, the number of "Prosvita" centres in the Polesie countryside increased massively from 18 to $112 .{ }^{56}$ The founded centres were probably influenced mostly by sympathisers and members of the Sel-Rob and communists. The "Prosvita" centres were established mainly in the counties of Brest, Kobryn and Drahichyn, and so the organisation in these territories took on a mass character, while the eastern parts of the Polesie voivodeship remained outside its reach.

The rapid increase in the number of "Prosvita" centres, full of radical element, undoubtedly favoured the politicisation of the organisation, while its educational and cultural activities were pushed aside. Ultimately, a serious dispute occurred between the leadership of "Prosvita" in Brest, and the management of its individual centres in terms of their political views and further development of the organisation. Under pressure from the authorities, the membership fee was raised from 50 groszys to 3 zlotys, which according to the board was to remove the radical element from the organisation and lead to healing the entire situation. In reality, the conflict significantly weakened the influence of "Prosvita" in the Polesian countryside. The number of members of the rural centres from 1930 onwards began to gradually decline, and from 1933 the organisation was already in a state of vegetation. ${ }^{57}$

From the point of view of state administration, the circles of "Prosvita" were probably nothing more than a cloak for activities referred to as subversive. At this point a question arises: could the short lifespan of "Prosvita" significantly boost national awareness among the Polesians? Indirectly in favour of a positive answer are the words of a Drahichyn resident in a letter to Senator Kysilevska from April 1934: "we realised who we are when Ukrainian libraries and reading rooms came to us, when we began to read Ukrainian newspapers and books". 58

${ }^{54}$ AAN, Voivode Office in Brest-on-the-Bug, no. 9, "Meldunek sytuacyjny nr 22 od 27/V. do 2/VI.1928 roku", f. 120.

55 Э. Мазько, “Палессе ў канцэпцыях беларускіх палітычных партый Заходняй Беларусі”, in: Загароддзе-3, eds. Ф. Клімчук, А. Энгелькінг, В. Лабачэўская, Мінск, 2001, р. 149.

56 В. Місіюк, “Просвіта на Поліссі (1923-1938 рр.)”, Наукові записки Національного університету "Острозька академія": Історичні науки, 2013, nо. 21, p. 139.

57 "Raport sporządzony przez Wydział Bezpieczeństwa Urzędu Wojewódzkiego Poleskiego o rozwoju ukraińskiego ruchu narodowościowego na Polesiu w latach 1918-1933”, in: Polesie w polityce, p. 145.

58 The National Library in Warsaw (hereafter: BN), mf 69743, Materials from Olena Kysilevska, f. 854. 
In general, the development of the Belarusian School Society in Polesie followed a similar pattern. The centres of the organisation were established mainly in two northern counties of the voivodeship - Kosava and Pruzhany. As a result of an effective absence of moderate Belarusian activists from Polesie, a more radical element dominated the Society from the very beginning. After the dissolution of the BWRH in the spring of 1927, some of its former members probably joined the ranks of the Society. In 1933 the organisation in Polesie effectively disappeared.

The presence of activists with centre-right views in the Ukrainian movement in Polesie was also reflected in the work for the Ukrainisation of the Orthodox Church. Members of the Ukrainian Citizens Committee in Polesie submitted a letter to Archbishop Alexander of Pinsk with the project of using the Ukrainian language in the Orthodox church life. The hierarch reacted quite favourably to this proposal, but made its implementation dependent on the will of the church community and local conditions in individual parishes. ${ }^{59}$ In January 1928, the Ukrainian Orthodox Church Congress was held in Brest, which requested the creation of a separate diocese led by a Ukrainian bishop and using Ukrainian as its liturgical language. ${ }^{60}$

Polesie in the interwar period was in a way predestined for the expansion of Belarusian and Ukrainian movements. In 1923, such a scenario was also assumed by the national administration. The Polesian voivode Stanisław Downarowicz speculated that Belarusian and Ukrainian factors could shake hands over Pripyat in the absence of consistency and determination on the part of the authorities of the Second Polish Republic. ${ }^{61}$ The interwar period was to become a window of opportunity for Belarusian and Ukrainian projects in Polesie. The reality proved to be completely different. The region remained on the side lines of the influences of these two nations. National agitation, most often closely related to the activities of radical left-wing parties, was ruthlessly fought by the police and security forces.

\section{Instead of an epilogue. Wacław Kostek-Biernacki and the nationality issue in Polesie in the 1930s}

It may seem that the relative rivalry of national projects ended in September 1939. In reality, a clear breakdown of national canvassing in the region can be observed as early as at the beginning of 1933. The new voivode of Polesie, Wacław KostekBiernacki, a firm supporter of the Piłsudski camp, at the same time fundamentally dissociated himself from the programme assumptions of the nationality policy of the Sanation governments. The leading concept of his politics was to be the

59 PAOB, no. f. 1, op. 9, d. 330a, "Ukraiński Komitet Obywatelski”, March 1928, f. 83.

60 В. Мисиюк, “Национальные процессы и церковь в Полесском воеводстве (1921-1939 гг.)”, Перекрёстки, 2009, nо. 1-2, p. 227.

${ }^{61}$ Program wojewody poleskiego Stanisława Downarowicza, p. 25. 
absolute national unification of the Polish state. Polesie became a training ground for implementing such ideas.

Based on the above assumption, Kostek-Biernacki was sceptical towards attempts to reach agreement with national minorities, especially with Ukrainians. The "Volhynia Experiment" by Henryk Józewski was a particularly negative point of reference. It should be emphasised that in Kostek-Biernacki's view all variants of a federation were a fictitious solution.

The voivode wrote:

But we cannot afford a federation. I believe that anyone who would raise such an idea in Poland - so disastrous for the uniformity, and thus the power of the state, would be considered a great pest by all spheres of Polish society, with the sole exception of communists working for the Russian state. In the interest of its existence, the Republic of Poland must be and will be a homogeneous organism, and never a biological Siamese, qualifying for a museum of curiosities and for a mockery of weaknesses, as the former Austria-Hungary. ${ }^{62}$

Colonel Kostek-Biernacki, hailing from military circles, had almost unlimited power in Polesie until September $1939 .{ }^{63}$ The socio-political unit in the voivodeship was headed by the voivode's personal adjutant, Kazimierz Rolewicz. The "barrack order" was transferred to public life to an equal extent. This style of governing was appreciated by Polesian peasants. In a sense, Kostek-Biernacki created his own image as a strict but fair "host of the Polesie land" ${ }^{64}$

The voivode sought to eliminate all non-Polish influence in Polesie. The pretext was communist activity conducted in institutions of national minorities. Belarusians did not have great leverage in Polesie, and during the period of Kostek-Biernacki's rule the Belarusian movement halted altogether. In the period of 1932-1934, no traces of any Belarusian activity were recorded in the region. ${ }^{65}$ After the riots in the Kamin-Kashyrskyi county, the Ukrainian party Sel-Rob was dissolved, as it was deemed an accessory to the communist movement. Subsequently, the "Prosvita" centres were closed under the pretext of being in the grip of the subversive element. In December 1933, only the Brest branch of "Prosvita" was active in the Polesie voivodeship, with 48 members.

The pressure was also applied to the Ukrainian economic centres in Polesie. Members of Ukrainian cooperatives were persuaded to join Polish cooperatives in various ways. Typically, the police punished them with fines as a result of minor shortcomings in the work of their establishments. In addition, in some

62 P. Cichoracki, "Memoriał narodowościowy wojewody poleskiego Wacława Kostka-Biernackiego z 8 września 1934 r.", Wrocławskie Studia Wschodnie, 2012, no. 16, p. 129.

${ }^{63}$ From February to September 1937 Jerzy de Tramecourt performed the duties of governor of Polesie.

${ }^{64}$ Śleszyński, Województwo poleskie, p. 56.

${ }^{65}$ PAOB, no. f. 1, op. 9, d. 1022, “Sprawozdanie sytuacyjne nr 10 za październik 1934 r.”, f. 59. 
cases unjustified suspicions of communist propaganda were aimed at them. There were incidents of detaining individuals from outside the voivodeship, carrying out checks of Ukrainian institutions in Polesie. In April 1934, the inspector Dmytro Esterniuk from Lviv was arrested by the police and spent over a day in detention, accused of acting for the CPWU. ${ }^{66}$ Eventually, Ukrainian cooperatives in Polesie ceased to exist or were subordinated to Polish institutions by 1935.

In the reality of the 1930s Polesie, individuals with a developed non-Polish national awareness were practically cut off from institutional channels of communication with their compatriots. Minority press struggled to reach Polesie, and those who subscribed it were blacklisted. There were cases of searching such individuals and charging them with subversive activity. It caused great resentment, and in some cases even the intention to emigrate, e.g. to Argentina. ${ }^{67}$

After the structures of the Ukrainian movement in Polesie were effectively destroyed, systematic preventive work was carried out. Southern and south-western borders of the voivodeship were sealed against Ukrainian influences, following the model of the Sokal border. ${ }^{68}$ It was recommended that any preventive measures should be used in order to stop Ukrainian agitators from entering Polesie. ${ }^{69}$ There were cases of detention, arrest and then expulsion from the voivodeship of even itinerant traders of Ukrainian nationality. ${ }^{70}$

Preventive action was also taken in relation to alleged attempts of Russifying Polesie. County authorities were ordered to oppose the "completely unconscious, but harmful propaganda of Russianness". They were to intervene in the case of retail trade in objects with Russian wording or inscriptions. ${ }^{71}$ In December 1938, the starosta of Luninets reported to the voivode office in Brest that he had issued a regulation on the prohibition of trade in goods with Russian descriptions. The pretext was the discovery of such writing on packages of sewing needles sold in Jewish shops. ${ }^{72}$

The outcome of the administration headed by voivode Kostek-Biernacki was the complete disappearance of nationality-related activities in Polesie. In fact, even

${ }^{66}$ PAOB, no. f. 1, op. 10, d. 222, “Spółdzielnie ukraińskie, zjazd w Brześciu n/B”, April 1934, f. 23-25.

${ }^{67} \mathrm{BN}, \mathrm{mf}$ 69743, Materials from Olena Kysilevska, f. 878.

68 The Sokal border (from the city of Sokal) - an unofficial term for the administrative border between Eastern Galicia on one side, and Volhynia and Chełm Land on the other. The authorities of interwar Poland politically upheld the existence of this informal border in order to prevent the expansion of the Ukrainian national movement from Eastern Galicia to other areas of the Second Polish Republic inhabited by the Ukrainian population.

${ }^{69} \mathrm{PAOB}$, no. f. 2, op. 2, d. 333, "Korespondencja brzeskiego starosty powiatowego z Poleskim Urzędem Wojewódzkim z 1VII 1937 r.”, f. 43.

70 PAOB, no. f. 1, op. 10, d. 1519, "Penetracja i propaganda ukraińska na Polesiu", December 1938, f. 5.

${ }^{71}$ PAOB, no. f. 1, op. 9, d. 108, "W sprawie propagandy rosyjskiej”, May 1938, f. 18.

72 PAOB, no. f. 2002, op. 2, d. 1054, "W sprawie propagandy rosyjskiej”, December 1938, f. 7. 
the smallest attempts of national agitation were interpreted by the authorities as subversive activities. Therefore, it should be assumed that Kostek-Biernacki's actions stopped the progress of nation-forming processes in the region. The young generation of Polesians, who grew up under Polish rule, was essentially as passive in terms of their nationality as their fathers and grandfathers. At the end of the 1930s, Polesie remained a hermetic territory, resistant to any external influences.

\title{
The Nationality Issue on the Peripheries of Central and Eastern Europe. The Case of Polesie in the Interwar Period
}

\begin{abstract}
The territory of Polesia in the interwar period was an area of competition between the national movements of Belarusian, Polish, Russian, and Ukrainian communities. In the Polesia Province, the scope of activity and intensification of national factors were not the same. An influence of the Belarusian movement was seen only in the north of the province, in the districts of Kosava and Pruzhany. The more active in Polesia Ukrainian movement was the strongest in southern, and south-western districts: of Brest on the Bug, Kobryn, and Kamin-Kashyrskyi. Russians were the most successful in the cities of Brest and Pinsk, and in the eastern part of the region, in the neighbourhood of the towns of Luninets and Davyd-Haradok, where influences of the Belarusian and Ukrainian movements were minimal. But the idea of "the great Russian nation" was gradually becoming an anachronism within the borders of the Second Republic of Poland.

Poland was an active player in the arena of national affairs in Polesia, as it sought to gain the support of local people through a unification policy of the state apparatus. The apogee of the Polonization action was in 1932-1939, after the office of Polesia voivode was taken by Col. Wacław Kostka-Biernacki. Activists of various national movements in Polesia were actively fought against by the State authorities. The voivodeship administration hampered all non-Polish national agitation among inhabitants of the region. The government of the Second Polish Republic did not succeed in combating civilisational backwardness in Polesia. An average inhabitant of the region was, in the first place, a member of his local rural community and often had no idea that for the State administration he was a Pole, for an Orthodox priest he was a Russian, and for a radical rural intellectual - a Belarusian or Ukrainian. A passive attitude of the majority of local people towards the question of nationality was still common at the end of the interwar period.
\end{abstract}

\section{Национальный вопрос на окраине центрально-восточной Европы. Случай Полесья между двумя войнами}

\section{Аннотация}

В межвоенный период в Полесье имело место соперничество на национальной почве между белорусскими, польскими, русскими и украинскими кругами. В Полесском воеводстве диапазон действий и степень интенсивности упомянутых национальных факторов не были однородными. Влияние белорусского движения было заметно только на севере Полесья - в Косовском и Пружанском поветах. У более стихийного украинского 
движения в Полесье больше всего плацдармов находилось южных и юго-западных поветах - Брестском, Кобринском, а также Каширском. Русские имели самый большой успех в городах - Бресте и Пинске, а также на востоке воеводства в окрестностях Лунинца и Давид-Городка, где влияние белорусского и украинского движений было ничтожно. Однако идея «великого русского народа» в границах Второй Речи Посполитой постепенно становилась анахронизмом.

Польша являлась активным игроком на Полесском национальном поле, пытаясь привлечь местное население посредством унификационных действий государственного аппарата. Полонизационная акция достигла апогея в 1932-1939 годах, после вступления в должность Полесского воеводы полковника Вацлава Костка-Бернацкого. Власть последовательно боролась с деятелями отдельных национальных движений в Полесье. Воеводская администрация активно препятствовала ведению всякой непольской национальной агитации среди полещуков.

Властям Второй Речи Посполитой определенно не удалось преодолеть огромную цивилизационную отсталость в Полесье. Среднестатистический полещук оставался, прежде всего, членом сельской общины и часто не имел понятия, что для государственной администрации - он - поляк, для православного священника - русский, а для радикального сельского интеллигента - белорус или украинец. Пассивная позиция большинства полещуков по национальному вопросу продолжала быть всеобщим явлением к концу межвоенного двадцатилетия.

Перевод Агнешка Поспишиль

\section{Bibliography}

\section{Archive material and manuscripts}

Archiwum Akt Nowych

Urząd Wojewódzki w Brześciu nad Bugiem (Urząd Wojewódzki Poleski)

Biblioteka Narodowa

Materiały po Olenie Kisielewskiej (mf 69743)

Państwowe Archiwum Obwodu Brzeskiego

Starostwo Powiatowe Brzeskie (f. 2)

Starostwo Powiatowe Łuninieckie (f. 2002)

Starostwo Powiatowe Pińskie (f. 2001)

Urząd Wojewódzki Poleski (f. 1)

Zakład Narodowy im. Ossolińskich (Dział Rękopisów)

sygn. 15641/II/t.1 (mf 10159), Antoni Zięba, "Pamiętnik pedagogiczny. Wspomnienia i refleksje", vol. 1 [years 1900-1939]

sygn. 16731/II (mf 35885), Stanisława Cybulska-Białowieska, “Moje wspomnienia (lata 19221945)"

\section{Press}

Под небом Полесья, Пинск, 1931

Наше время, Вильно-Варшава, 1934

Tęcza, Poznań, 1938

Biuletyn Polsko-Ukrainski, Warszawa, 1938 


\section{Secondary literature}

Cichoracki P., Droga ku anatemie. Wacław Kostek-Biernacki (1884-1957), Warszawa, 2009.

Cichoracki P., "Działalność wywrotowa w województwach północno-wschodnich II Rzeczypospolitej Polskiej - jedno z następstw Wielkiej Wojny”, in: Wojna i ludzie. Społeczne aspekty I wojny światowej w Europie Wschodniej, ed. D. Michaluk, Ciechanowiec, 2015.

Cichoracki P., Komuniści na Polesiu w latach 1921-1939, Łomianki, 2016.

Cichoracki P., "Memoriał narodowościowy wojewody poleskiego Wacława Kostka-Biernackiego z 8 września 1934 r., Wrocławskie Studia Wschodnie, 2012, no. 16.

Cichoracki P., Województwo poleskie 1921-1939. Z dziejów politycznych, Łomianki, 2014.

Ciesielski S., "Kresy Wschodnie - dynamika przemian narodowościowych", in: Kresy Wschodnie II Rzeczypospolitej. Przekształcenia struktury narodowościowej 1931-1948, ed. S. Ciesielski, Wrocław, 2006.

Drugi powszechny spis Rzeczypospolitej Polskiej z dn. 9 XII 1931 r. Mieszkania i gospodarstwa domowe. Ludność. Stosunki zawodowe. Województwo Poleskie, Warszawa, 1938.

Dworakowski S., Szlachta zagrodowa we wschodnich powiatach Wołynia i Polesia. Relacje $z$ terenu, Warszawa, 1939.

Gierowska-Kałłaur J., Zarząd Cywilny Ziem Wschodnich (19 lutego 1919 - 9 września 1920), Warszawa, 2003.

Gomółka K., Białorusini w II Rzeczypospolitej, Gdańsk, 1992.

Grott O., Instytut Badań Spraw Narodowościowych i Komisja Naukowych Badań Ziem Wschodnich w planowaniu polityki II Rzeczypospolitej Polskiej na Kresach Wschodnich, Kraków, 2013.

Krysiński A., "Liczba i rozmieszczenie Ukraińców w Polsce”, Sprawy narodowościowe, 1928, no. 6.

Massis E., "Próby wykształcenia tożsamości narodowej u ludności słowiańskiej na Polesiu w pierwszych latach II Rzeczypospolitej Polskiej (1920-1928)", Adeptus, 2015, no. 5.

Michaluk D., Białoruska Republika Ludowa 1918-1920: u podstaw białoruskiej państwowości, Toruń, 2010.

Obrębski J., Polesie, ed. A. Engelking, Warszawa, 2007.

Pierwszy powszechny spis Rzeczypospolitej Polskiej z dnia 30 września 1921 roku. Mieszkania. Ludność. Stosunki zawodowe. Województwo Poleskie, Warszawa, 1926.

Polesie w polityce rządów II Rzeczypospolitej, ed. W. Śleszyński, Białystok-Kraków, 2009.

Protokoły i raporty zebrań wojewodów i starostów - województwo poleskie, ed. W. Śleszyński, Kraków, 2014.

Śleszyński W., Województwo poleskie, Kraków, 2014.

Tomaszewski J., Z dziejów Polesia 1921-1939. Zarys stosunków społeczno-ekonomicznych, Warszawa, 1963.

Wasilewski L., Sprawa Kresów i mniejszości narodowych w Polsce, Warszawa, 1925.

Wasilewski L., Wspomnienia 1870-1904 (1914). Fragmenty dziennika 1916-1926, diariusz podróży po kresach 1927, eds. J. Dufrat, P. Cichoracki, Łomianki, 2014.

Винниченко I., Украӥнці Берестейщини, Підляшщя й Холмщцини в першій половині ХХ ст. Хроніка подій, Київ, 1997.

Дмитріюк В., Дорогами війни та миру, [n.p.] 2012.

Ильин А., “Шалаш поэтов”, Гістарычная брама: гісторыя $і$ культура Палесся, 2004, nо. 1.

Ильин А., “Всплеск русского движения в Давид-Городке в 1928-1931 годах”, in: Берасцейскі хранограб: зб. навук. праи, еd. М. Часноўскі, по. 4, Брэст, 2004.

Кисілевська О., По рідному краю, Коломия, 1935.

Мазько Э., "Палессе ў канцэпцыях беларускіх палітычных партый Заходняй Беларусі", in: Загароддзе - 3, eds. Ф. Клімчук, А. Энгелькінг, В. Лабачэўская, Мінск, 2001. 
Мисиюк В., “Исследование национальных процессов в Восточной Европе на примере Полесского воеводства (1921-1939 гг.)”, Перекрёстки, 2007, no. 3-4.

Мисиюк В., "Национальные процессы и церковь в Полесском воеводстве (1921-1939 гг.)", Перекрёстки, 2009, nо. 1-2.

Місіюк В., “Просвіта на Поліссі (1923-1938 рр.)", Наукові записки Національного університету 'Острозька академія': Історичні науки, 2013, по. 21.

Монтвилов М., Русская гимназия в Бресте на Буге 1919-1939 г2., Ним-Брест-Минск, 1996.

Одрач Ф., “Наше Полісся”, Пам’ятки України, 2002, nо. 3-4.

Пашкевіч А., “Нацыянальныя працэсы ў Палескім ваяводстве ў 1920-я гг. праз прызму вынікаў выбарчых кампаній у польскі парламент”, Arche, 2013, no. 4.

Терешкович П., Этническая история Беларуси ХIX - начала XX в. в контексте Центрально-Восточной Европь, Минск, 2004.

Ціхарацкі П., “Паляшук’ - аб’ект цывілізацыйнай місіі і пакрыўджаны суайчыннік. Праваслаўныя вясковыя жыхары Палескага ваяводства ў польскай папулярнай літаратуры міжваеннага перыяду", Arche, 2014, no. 7-8.

Швайко В., “Русская диаспора в Польше в 20-30 гг. XX в.”, Диаспоры, 2004, no. 2.

Pavel Ablamski, PhD student at the Tadeusz Manteuffel Institute of History of the Polish Academy of Sciences. Research interests: national minorities and nationality policy of the interwar East-Central Europe, political and social history of the Eastern voivodeships of the Second Polish Republic (ablamski@gmail.com). 